\title{
ABSORPTANCE OF DIFFERENT LOCAL COATED SURFACES TO SOLAR RADIATION IN EGYPT
}

\author{
El-Gayar, S.M.1, H.E. Gad' and H. H. Gad
}

\begin{abstract}
This study was carried out on the roof of the Thermal Eng. Laboratory, Mechanical power Dept., Fac. of Eng., Mansoura Univ., during selected clear days of April and one clear day of May, 2013. An experimental set up was designed and installed to measure the absorptance of 11 coated surfaces and one sheet without color. Then, the temperature of tested surfaces were calculated. The results showed that, G.I sheets coated with black bored $(\mathrm{Bb})$, polish black $(\mathrm{Pb})$, brown $(\mathrm{Br})$, red $(\mathrm{R})$, violet $(\mathrm{V})$, green $(G)$, blue (Blu), G.I. sheet without color, dark yellow $(Y d)$, yellow $(Y)$, silver $(S)$ and white $(W)$, are 0.92, 0.886, 0.888, 0.855, 0.852, 0.843, $0.830,0.802,0.788,0.785,0.746$, and 0.666 respectively. A liner equation was derived to predict the absorptance $(\alpha)$ of these colored oil painted surfaces basing upon their temperature (T) as follows:
\end{abstract}

$$
\alpha=0.008 \mathrm{~T}+0.053 \quad R^{2}=0.996
$$

This equation may be applied at agricultural field to select the surface coating colors of buildings, greenhouses, soil mulching poly ethylene sheets and absorbers (solar collectors).

\section{INTRODUCTION}

$\mathrm{n}$ the present electric energy crisis, many engineers and researches
are concentrated on the ways of energy saving. The influence of
painting color on the absorptance of building surfaces to solar radiation plays an important role in space warming and energy savings. The effect of color on the thermal performance of building integrated solar collectors is reported by Anderson et al (2010). Although white color is the most common used in hot countries, other mineral based coatings for buildings and urban structures have developed and analyze Kolokotsa et al (2012).

\footnotetext{
${ }^{1}$ Agric. Eng. Res. Inst., A. R. C, Giza, 256, Egypt,.

${ }^{2}$ Fac. of Eng., Mansoura University, 35516, Egypt,

${ }^{3}$ Fac. of Eng., Mansoura University, 35516, Egypt.
} 
On the other hand, the temperatures below and above the mulch through the absorption, transmission and reflection of solar energy are affected by its color. Black plastic mulch is the most popular color used in commercial vegetable production especially for weed control. As a blackbody absorber, this plastic absorbs most incident solar radiation, including visible, infrared and ultraviolet light. Black paint is the most common used coating to absorb solar radiation in solar collectors and buildings Zhu and Zhao (2010) and Hiroki et al (2013). White plastic mulches can be used to establish crops in the summer, when a reduced soil temperature might be beneficial. Co extruded white on black plastic mulch helps cool the soil (white) while controlling ling weeds (black). Red plastic mulch has been shown to increase tomato yields and quality in some trials and reduce the severity of early blight in others. It also increases yields of honeydews, muskmelons and zucchini. In addition, it significantly increases soil temperatures. Yellow, orange, blue and gray plastic mulches also have been evaluated. The different radiation patterns that are reflected back into the canopies of various crops from these mulches affect plant growth and development in different ways. Some colors like yellow attract certain insects like green pea, aphids and cucumber beetles as reported by Lamont (1999). Such mulches might be used in a field to grow "catch crops" to pull insects away from other crops.

Solar absorber coatings have attracted a great deal of interest because the efficiency of any solar collector system is strongly dependent on the ability of its absorber to convert solar radiation into heat. Performance of solar systems employing collectors with different colored absorber is studied by Kalogirou et al (2005). They concluded that black board coating is the best for solar absorber. Also, Nwosu and Wilfred (2008) studied the effect of an absorptive coating on solar energy storage in a Thrombe wall system.

A novel and affordable solar selective coating exhibiting higher solar absorption efficiency compared to the commercial black paint coating used in most ordinary solar water heating systems has been developed. These coatings have high absorptance to short wave solar radiation and 
low remittance to long wave radiation from hot absorbers. As an example, a coating is fabricated by embedding a metallic particle composed of a nickel-aluminum alloy into the black paint as mentions by Ehab (2010). Many other selective coatings are developed, studied Orela et al (2005) and Chao et al (2013). Nano technology has also come to the research line, to produce new coatings that enhance total solar radiation absorptance. Different colored are also developed and examined. Fabrication and optimization of highly efficient cermet-based spectrally selective have been studied by Esposito et al (2009). Measurement of the solar absorptance and thermal emittance are measured by James et al (2010).

In many cases, the need for low price local production coatings is essential to absorb more solar radiation for buildings, greenhouses and solar collectors. On the other hand, some buildings need to reduce their absorptance for solar radiation. In the present work, an experimental setup is designed and installed to test the absorptance of 11 locally oil coated surfaces and one sheet without color by measuring the surface temperature.

\section{MATERIAL AND METHODS}

\section{Experimental Setup and Procedure}

The setup consists of a wooden box $80 \mathrm{~cm}$ length, $60 \mathrm{~cm}$ width and a depth of $15 \mathrm{~cm}$ from inside. The box wall is $2.4 \mathrm{~cm}$ thickness and is painted white from inside and black color from outside to decrease the heat loss. The box is covered with $3 \mathrm{~mm}$ thickness glass cover and fixed on an iron frame with a tilt angle of $30^{\circ}$ to horizontal and facing south. A foam insulation layer ( $3 \mathrm{~cm}$ thickness) is fixed inside on the box bottom and $2 \mathrm{~cm}$ on sides. Twelve $(10 x 10) \mathrm{cm}$. galvanized iron (G.I) sheets of $0.8 \mathrm{~mm}$. thickness are fixed in the middle area of the back insulation as shown in Fig. 1. The sheets are coated black bored (Bb), polish black $(\mathrm{Pb})$, brown $(\mathrm{Br})$, red $(\mathrm{R})$, violet $(\mathrm{V})$, green $(\mathrm{G})$, blue $(\mathrm{Blu})$, dark yellow $(\mathrm{Yd})$, yellow $(\mathrm{Y})$, silver $(\mathrm{S})$ and white $(\mathrm{W})$. One sheet is kept without coating (GI). All sheets are fixed in $2 \mathrm{~mm}$. depression in the back insulation. 
The setup is suitably instrumented to measure the temperature at the twelve sheet centers, inner glass surface, outside box bottom temperatures and the ambient air temperature. The total solar radiation data are measured at the upper face of the apparatus and recorded at 30 minutes intervals by a solar power meter TES1333 with a measuring range of $2000 \mathrm{~W} / \mathrm{m}^{2}$, accuracy $\pm 5 \%$ and resolution $1 \mathrm{~W} / \mathrm{m}^{2}$.

The experimental work is carried out on the roof of the Thermal Eng. Laboratory, Mechanical power dept., Fac. of Eng., Mansoura Univ., at latitude of $31.0408^{\circ} \mathrm{N}$ and longitude of $31.486^{\circ} \mathrm{E}$. The experiments were performed during selected clear days of April and one clear day of May, 2013 from 6 am to 18 pm hours. The coatings are produced according to the Egyptian standard specifications No. 793 class 2. Factory: New Borg El Arab city second industrial zone, Alex. Film thickness: 50-60 $\mu \mathrm{m}$ dry film per single coat.

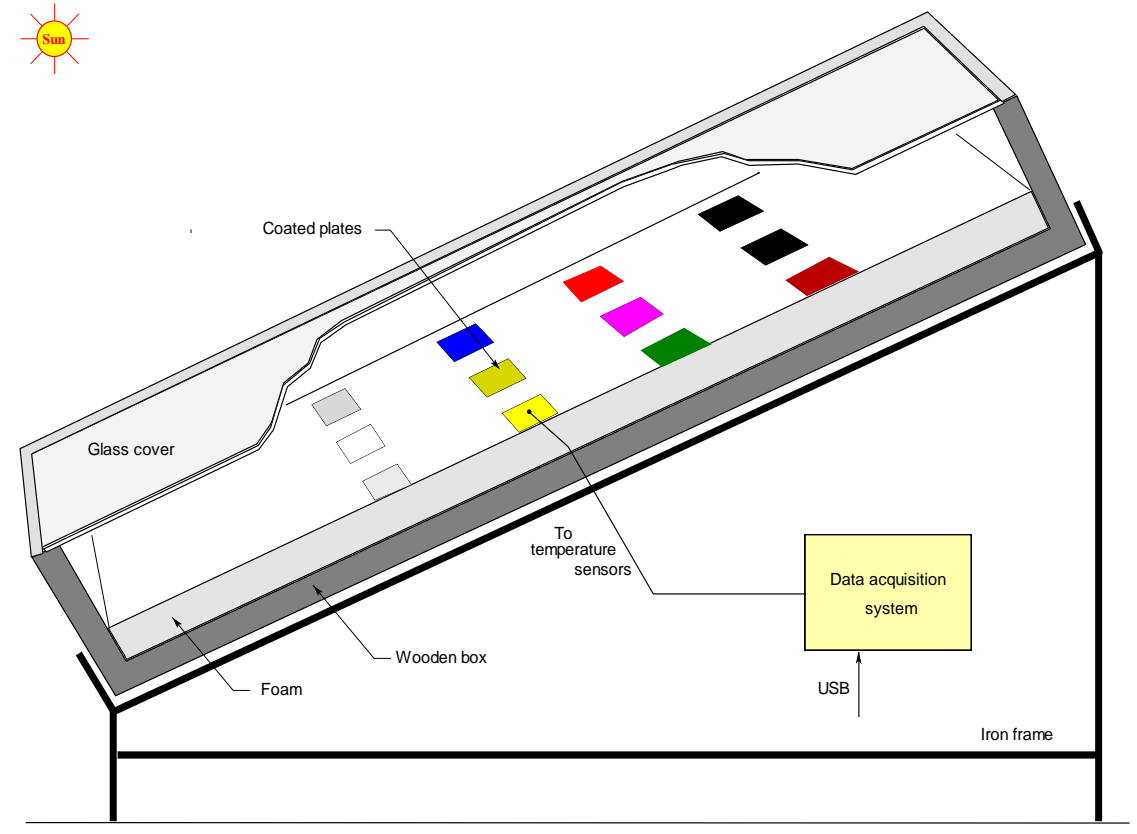

Figure 1 The experimental setup.

The temperatures are measured by sensors and recorded by a data acquisition system with a sampling rate that is adjusted to be 10 minutes. The 12 sheets are fixed in the insulation as seen in Fig. 2. 


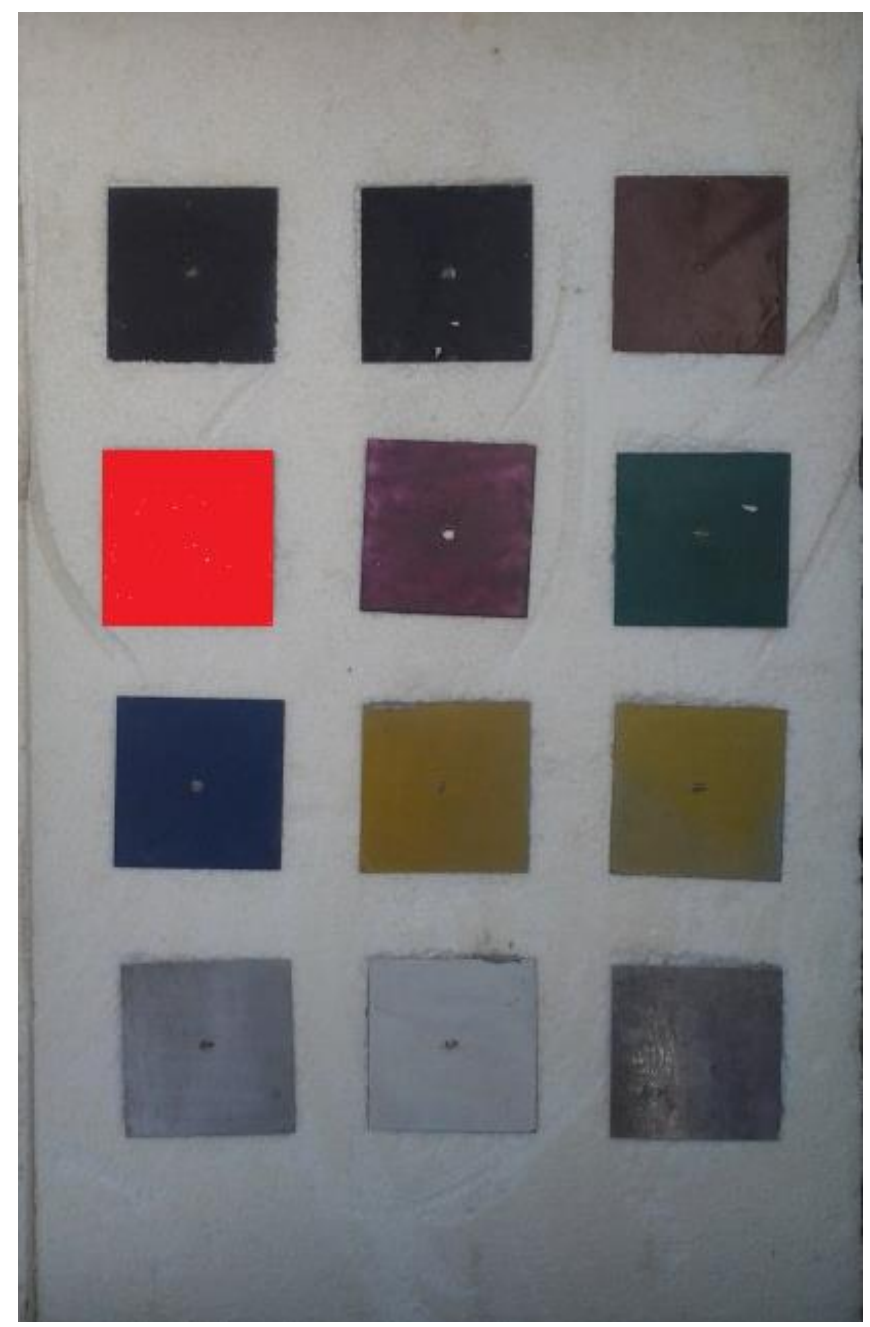

Figure 2 A photograph of the used coated GI sheets.

Figure 3 shows a photograph of the data acquisition system which consists of; master control board, Arduino board, power supply unit and sensors terminals unit, Gad and Gad (2015). The master control board is used for controlling the system by 4 press buttons and LCD screen. The Arduino board is used to measure sensors voltages and store their values in a secure digital (SD) card. The power supply unit is used to provide the appropriate voltages to the whole system. The sensors terminal unit is employed to ease the connection between sensors the system. 
A block diagram of the system is shown in Fig. 4. The main component of the master control board is the microcontroller PIC18F46K20 from Microchip Company with a memory size of (64 KB program and $3 \mathrm{~KB}$ data memory), makings it the most suitable for the data acquisition systems . In order to keep tracking the current time and the date, a dedicated Real Time Clock (RTC) chip DS1302 has been used and is connected to the PIC18F46K20 microcontroller via Serial Peripheral Interface (SPI) protocol system. The most important feature of the DS1302 is that, it has the ability to keep tracking of the current time and date even when the power supply is off by using a 3.3V backup battery as shown also in Fig. 3.

The Arduino board has been utilized to measure and store the sensors data on the SD card in CSV file formats. The main component of the board is ATMega2560, which it is a powerful microcontroller from ATMEL Company Ibrahim (2008). This microcontroller has a large memory size (256 KB program and $8 \mathrm{~KB}$ data memory) making it the most suitable for the filing system and the SD cards applications. The microcontroller ATmega2560 is connected to the SD card via the SPI protocol as shown in Fig. 3. Moreover, the ATmega2560 microcontroller can measure up to 16 analog sensors and up to 53 digital sensors because it has a huge number of Input/Outputs ( 86 pins). The USB connection is used to monitor the sensors data in real time as an option to the user. In order to connect the Arduino board, to the master control circuit a serial communication interface as shown in the same figure.

In this work, an analogue temperature sensor LM35DZ from National Semiconductor has been utilized. The output voltage of this high precision integrated circuit temperature sensor is linearly proportional to the temperature and it does not require any external calibration. Also, it provides typical accuracies of $\pm 0.25{ }^{\circ} \mathrm{C}$ at room temperature and \pm $0.75{ }^{\circ} \mathrm{C}$ over a full -55 to $+150^{\circ} \mathrm{C}$ temperature range. Moreover, this sensor has a very low self-heating, which it is less than $0.1^{\circ} \mathrm{C}$ in stagnant air. For a stable operation, the microcontroller must work in a moderate ambient temperature. 


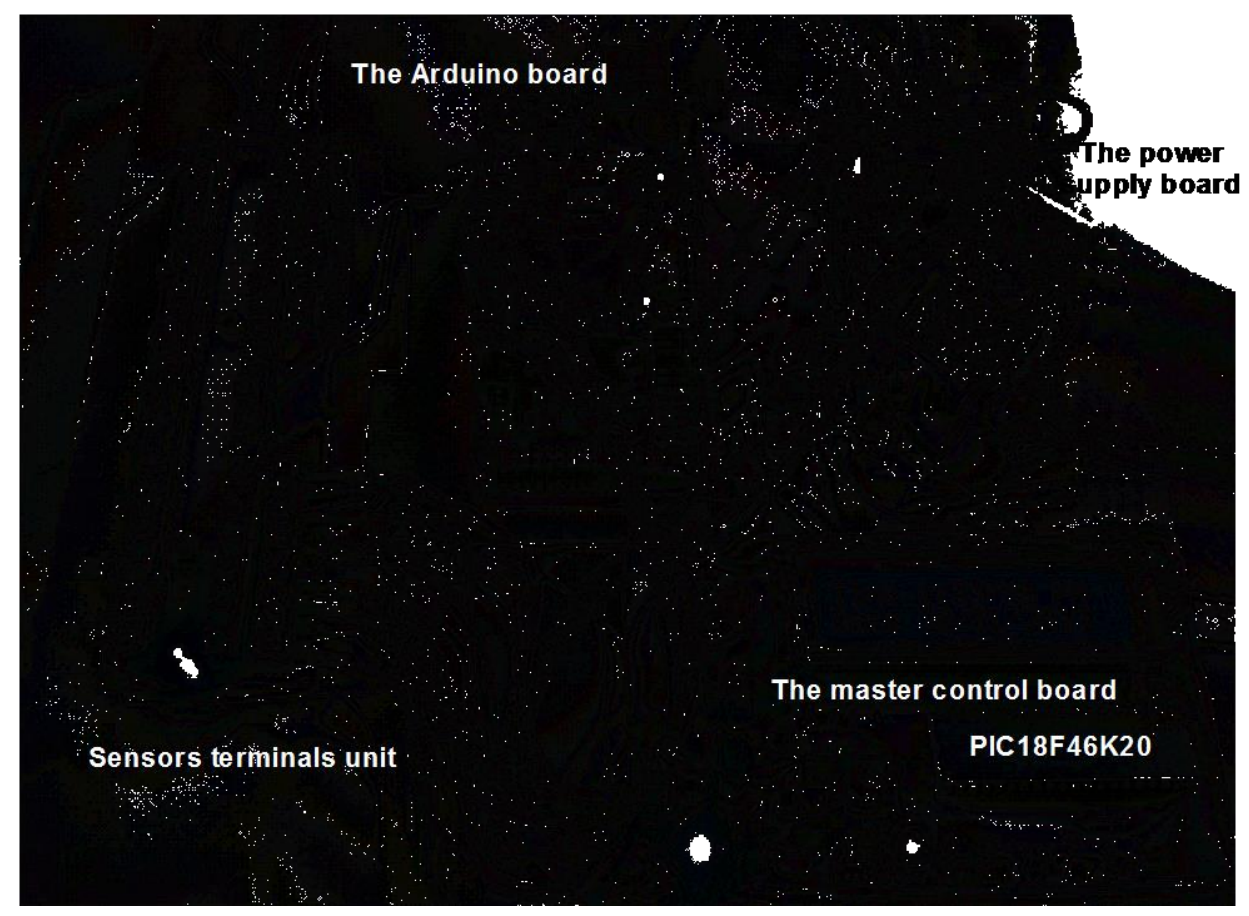

Figure 3 A photograph of the data acquisition system.

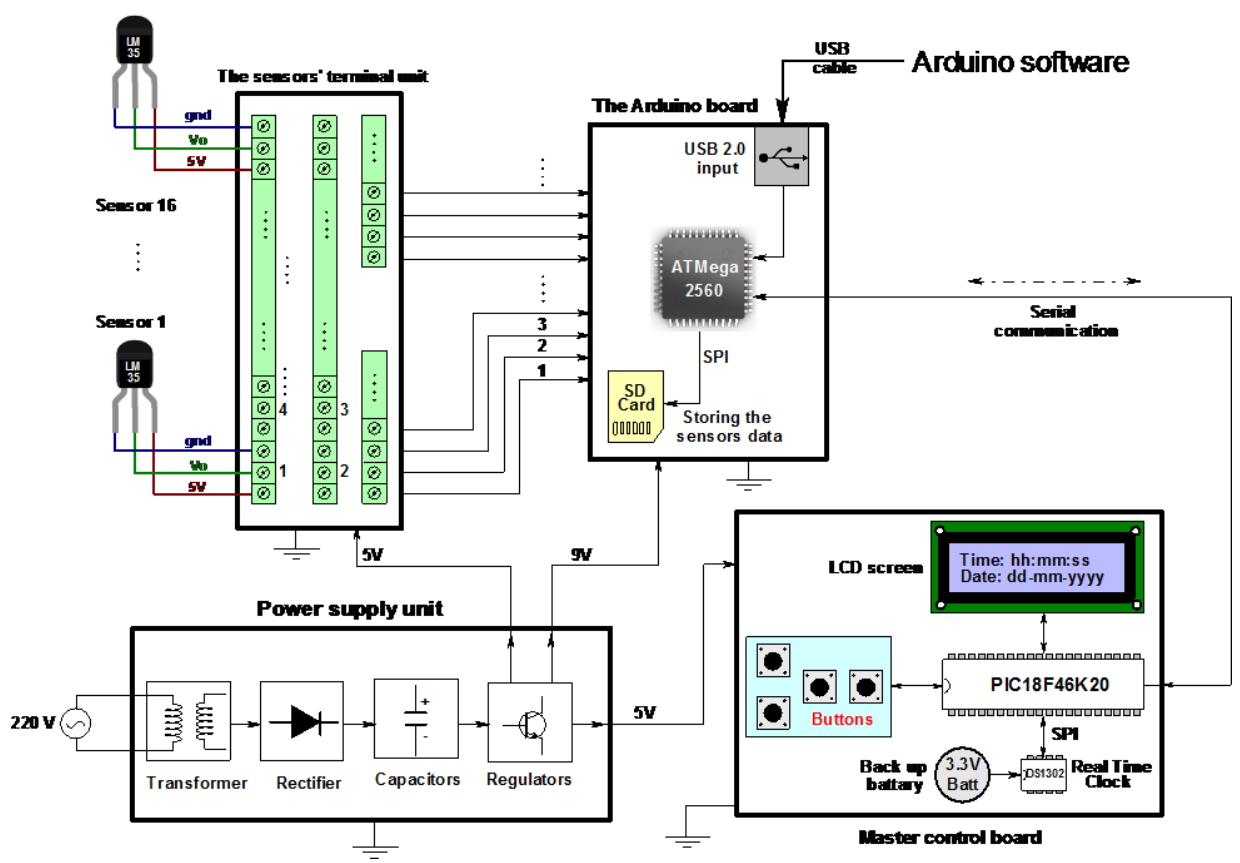

Figure 4 Block diagram of the data acquisition system. 


\section{Treatments and statistical design:}

The treatments of the coating surface colors i.e. black bored $(\mathrm{Bb})$, polish black $(\mathrm{Pb})$, brown $(\mathrm{Br})$, red $(\mathrm{R})$, violet $(\mathrm{V})$, green $(\mathrm{G})$, blue (Blu), dark yellow (Yd), yellow (Y), silver (S) and white (W) and one sheet is kept without coating (GI) were tested .The experiment was carried out and design statistically as a complete randomized design.

\section{Statistical Analysis:}

SAS computer software is used to carry out the analysis of variance test for the obtained data of surfaces absorbtance. L.S.D. test is applied to show the difference between treatments.

\section{Regression and Correlation Analysis:}

Microsoft Excel 2010 computer software is used to perform the simple regression and correlation to show the relation between the surfaces absorbtance and the sheets temperature.

\section{RESULTS AND DISCUSSIONS}

The transmittance of glass cover is calculated by measuring the normal solar radiation with and without the glass sheet. The test is carried out several times and yields an average transmittance $(\tau=0.88)$. If a solar radiation with intensity (I) hits the glass cover with, a part of the beam ( $\tau$ I) will be transmitted through it. If this part hits a coated plate with absorptance $(\alpha)$, the absorbed part will be $(\alpha \tau)$ I as shown in Fig. 5, is absorbed and consumed to heat up the sheet.

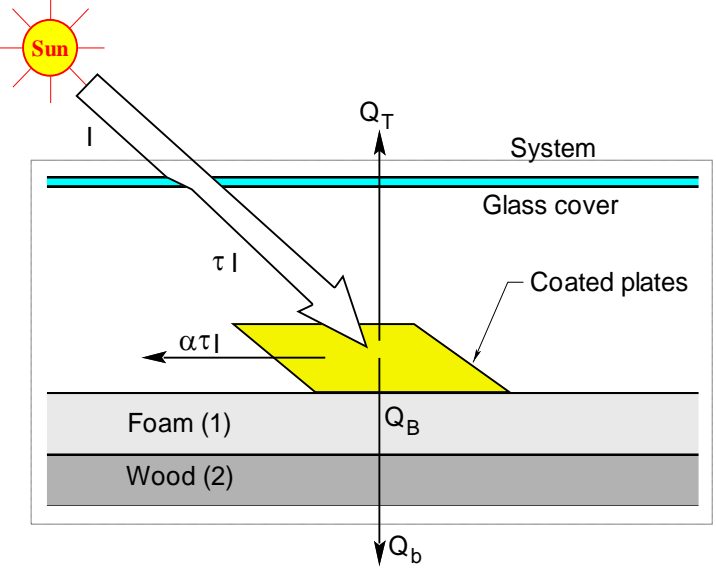

Figure 5 Solar radiation beam hitting a coated plate. 
If the top losses $\mathrm{Q}_{\mathrm{T}}$ and the bottom losses $\mathrm{Q}_{\mathrm{b}}$, the heat balance on the system with an area of one sheet $\left(\mathrm{A}=0.01 \mathrm{~m}^{2}\right)$ and height of the box shown in Fig. 5,

$$
\mathrm{I}=(\alpha \tau) \mathrm{I}+\left(\frac{\mathrm{Q}_{\mathrm{T}}}{\mathrm{A}}\right)+\left(\frac{\mathrm{Q}_{\mathrm{b}}}{\mathrm{A}}\right)
$$

Top losses are convection and radiation heat transfer from the glass cover to atmosphere. Bottom losses are due thermal conduction from the back and sides and convection to ambient air. The present system cannot be dealt as a flat plate collector or an air heater. Therefore, each plate will be considered alone, and absorbs solar radiation $(\alpha \tau)$ I which increases with temperature. The absorbed solar radiation can be expressed as,

$$
(\alpha \tau) \mathrm{I}=\mathrm{mcT}
$$

Where, $\mathrm{m}, \mathrm{c}$ and $\mathrm{T}$ are the mass and specific heat of iron, and sheet temperature respectively.

The experimental work is carried out in several days during April and May, but only four selected clear sky days are chosen to represent the results. The total solar radiation data measured on a tilted surface in these selected days are shown in Fig. 6 (a-d). It was noticed that, the peak intensity of the global solar radiation intensity was achieved at med-day (at 12 noon) as cleared in this figure.

The temperature of each sheet as a function of time in the same clear days is shown in Fig. 7 (a-d). All temperatures increase with time to a maximum value around noon and then decrease again. The ambient air temperature is shown to be the lowest temperature with a maximum value between 15 and 16 hours as shown in the figure. The box bottom temperature is higher than that of ambient in the order of $2-3^{\circ} \mathrm{C}$ approximately. The highest recorded temperature, as expected, is that of the sheet with blackboard paint. The lowest temperature recorded, as also expected, is that of the sheet with white paint as shown in the figure.

Since the sheet temperature increases with increasing its absorptance, it is necessary focus on each sheet temperature near 12 noon (from 11 to 13 hours). This is to avoid the effect of thermal capacity of the system. 


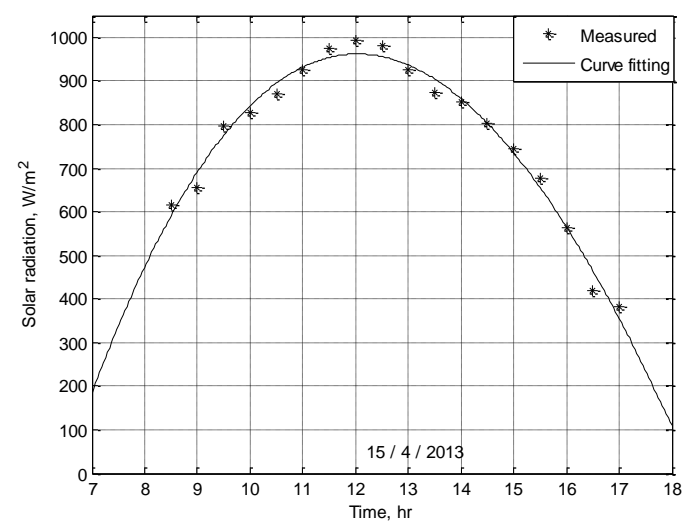

(a)

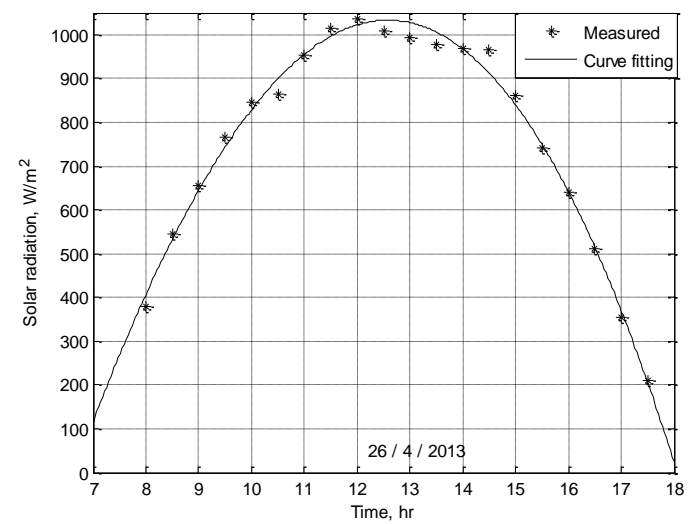

(c)

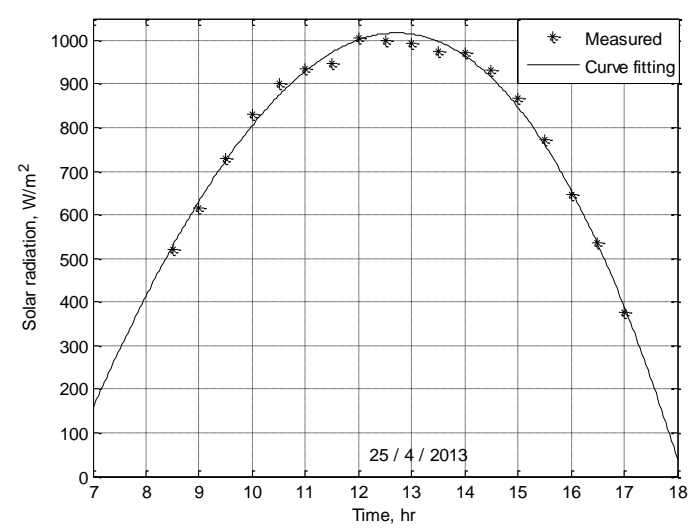

(b)

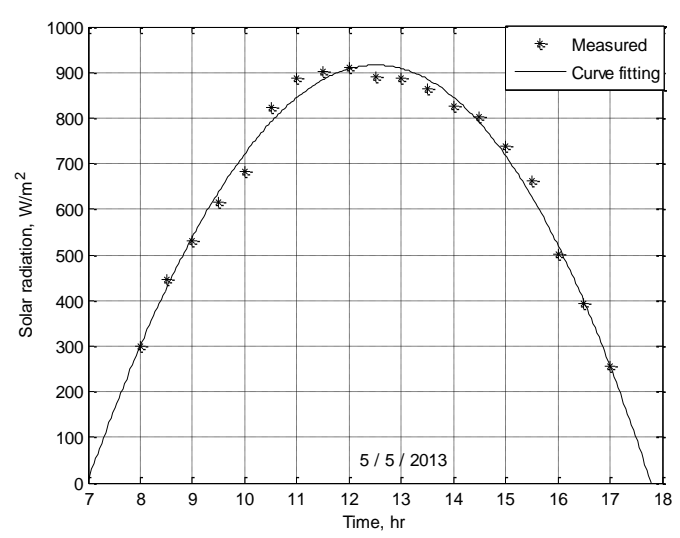

(d)

Figure 6 (a-d) Total solar radiation in selected experimental days.

Table (1) shows the average sheet temperatures and solar radiation in the selected days for different painted sheets and one sheet without painted from 11 to 13 hours. Many researchers such as Zhu and Zhao (2010) concluded that the absorptance of blackboard $(\mathrm{Bb})$ paint surfaces has an average value of 0.92 . On this base, results have also shown that, the G.I sheets coated with black bored $(\mathrm{Bb})$, polish black $(\mathrm{Pb})$, brown $(\mathrm{Br})$, red $(\mathrm{R})$, violet $(\mathrm{V})$, green $(\mathrm{G})$, blue (Blu), G.I. sheet without color, dark yellow (Yd), yellow (Y), silver (S) and white $(\mathrm{W})$, are 0.92, 0.886, 0.888, $0.855,0.852,0.843,0.830,0.802,0.788,0.785,0.746$, and 0.666 respectively. 


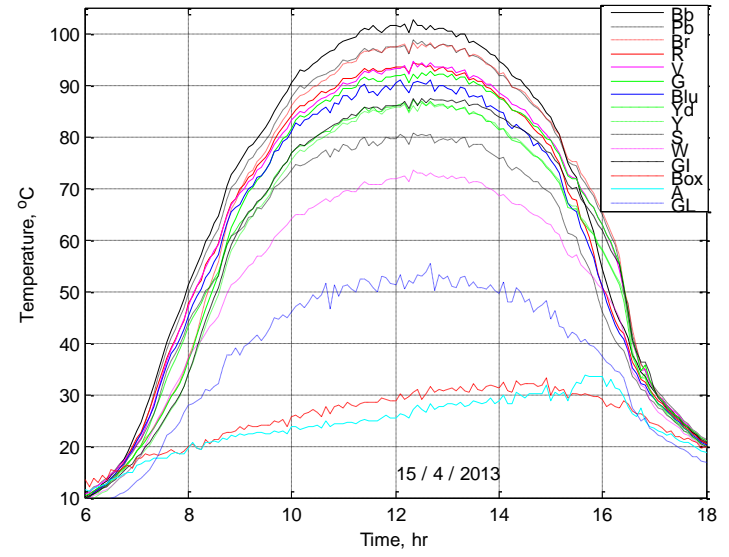

(a)

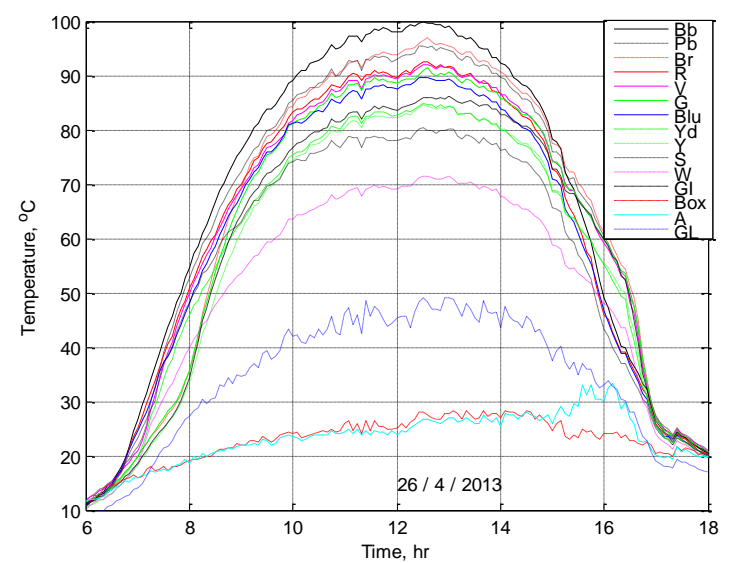

(c)

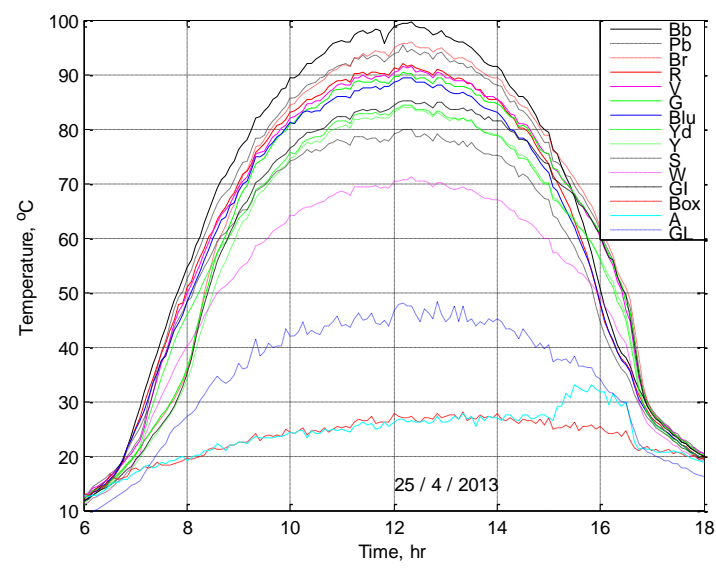

(b)

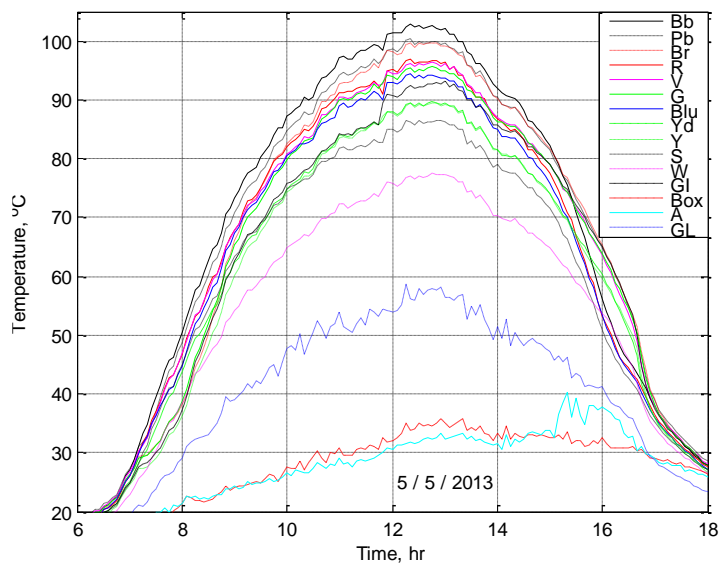

(d)

Figure 7 (a-d) Temperatures of different sheets in the system.

The analysis of variance test of the absorptance expression $(\alpha)$ shows that there is a significant difference between treatments due to color. L.S.D. test at 5\% level indicates that 0.92 surface absorptance higher significant different among other treatments.

Simple regression and correlation test shows that there is a positive relation between surface absorptance $(\alpha)$ and its temperature $(T)$ as follows:

$$
\alpha=0.008 \mathrm{~T}+0.053 \quad \mathrm{R}^{2}=0.996
$$




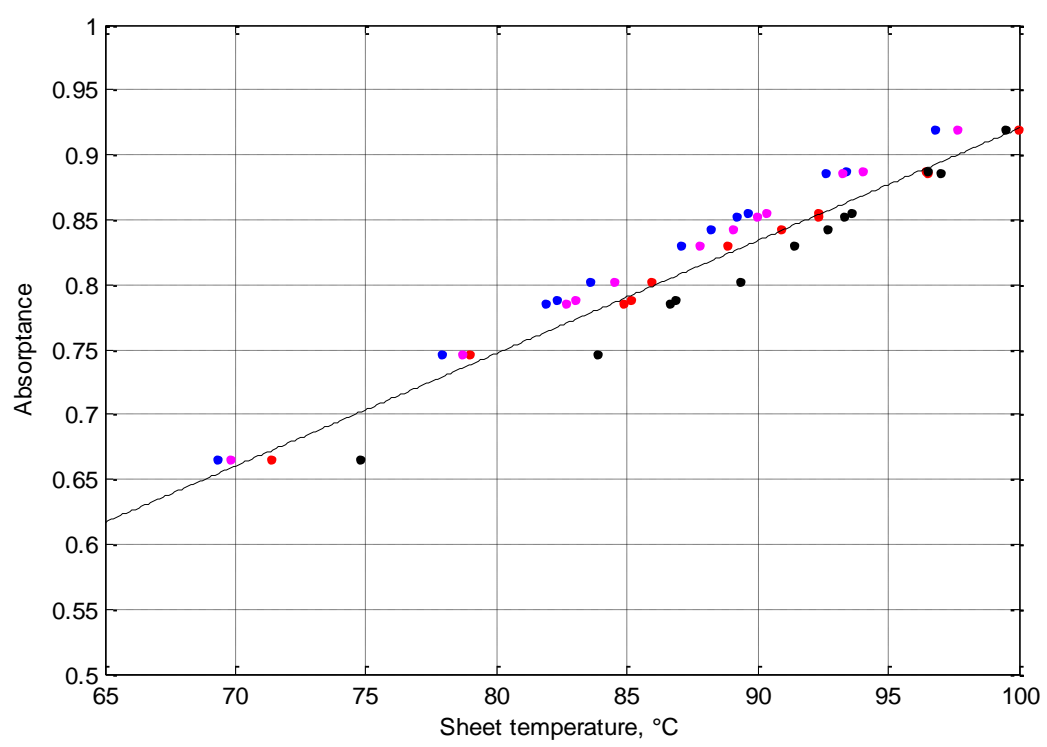

Figure 8 Experimental evaluation of absorptance variation with sheet temperature.

Table (1) Average results from 11 to 13 hours.

\begin{tabular}{|c|c|c|c|c|c|c|}
\hline Date & $15 / 4 / 2013$ & $25 / 4 / 2013$ & $26 / 4 / 2013$ & $5 / 5 / 2013$ & $\begin{array}{l}\mathrm{I}_{\mathrm{av}}, \\
\mathrm{W} / \mathrm{m}^{2}\end{array}$ & \\
\hline $\begin{array}{c}\mathbf{I}, \\
\mathrm{W} / \mathbf{m}^{2}\end{array}$ & 959.52 & 976.3 & 1001.74 & 896.38 & 958.485 & \\
\hline Color & $\mathrm{T},{ }^{\circ} \mathrm{C}$ & $\mathrm{T},{ }^{\circ} \mathrm{C}$ & $\mathrm{T},{ }^{\circ} \mathrm{C}$ & $\mathrm{T},{ }^{\circ} \mathrm{C}$ & $\mathbf{T}_{\mathrm{av}},{ }^{\circ} \mathrm{C}$ & $\alpha$ \\
\hline Bb & 99.95 & 96.78 & 97.61 & 99.45 & 98.45 & 0.920 \\
\hline $\mathbf{P b}$ & 96.51 & 92.55 & 93.23 & 97.01 & 94.83 & 0.886 \\
\hline $\mathrm{Br}$ & 96.39 & 93.34 & 93.97 & 96.49 & 95.05 & 0.888 \\
\hline $\mathbf{R}$ & 92.31 & 89.59 & 90.29 & 93.55 & 91.44 & 0.855 \\
\hline V & 92.33 & 89.20 & 89.93 & 93.30 & 91.19 & 0.852 \\
\hline $\mathbf{G}$ & 90.91 & 88.19 & 89.01 & 92.64 & 90.19 & 0.843 \\
\hline Blu & 88.82 & 87.02 & 87.72 & 91.37 & 88.73 & 0.830 \\
\hline GI & 85.94 & 83.58 & 84.48 & 89.29 & 85.82 & 0.802 \\
\hline Yd & 85.12 & 82.28 & 82.97 & 86.82 & 84.30 & 0.788 \\
\hline$Y$ & 84.81 & 81.88 & 82.62 & 86.64 & 83.99 & 0.785 \\
\hline $\mathbf{S}$ & 78.97 & 77.89 & 78.70 & 83.82 & 79.85 & 0.746 \\
\hline $\mathbf{W}$ & 71.33 & 69.27 & 69.82 & 74.79 & 71.30 & 0.666 \\
\hline
\end{tabular}

\section{CONCLUSION}

The absorptance of different surfaces to the total solar radiation depends mainly on its color. A surface with high absorptance absorbs more solar 
radiation and vice versa. To test the absorptance of 11 oil painted surfaces and the G.I sheet an experimental setup is designed and installed at Mansoura University. Local paints are used for surface coatings such as blackboard, polish black, brown, red, violate, green, blue, G.I. sheet without color, dark yellow, yellow, silver and white color. Results have shown that the absorptance of these sheets are 0.92, 0.886, 0.888, 0.855, $0.852,0.843,0.830,0.802,0.788,0.785,0.746$ and 0.666 respectively. A simple straight line correlation can be used to predict the absorptance of these colored oil painted surfaces.

\section{REFERANCES}

Anderson T.N., Duke M., and J.K., Carson (2010) "The Effect of Color on the Thermal Performance of Building Integrated Solar Collectors", Solar Energy Materials \& Solar Cells 94: 350-354.

Chao-C. C., Ching-Li H. and L. C., Cheng (2013) "Poly (Urethane)Based Solar Absorber Coatings Containing Nanogold", Solar Energy 91: 350-357.

Ehab A., (2010) "Testing of a New Solar Coating for Solar Water Heating Applications", Solar Energy 84: 1637-1643.

Esposito S., Antonaia A., Addonizio M.L., and S., Aprea (2009) "Fabrication and Optimization of Highly Efficient Cermet-Based Spectrally Selective Coatings for High Operating Temperature", Thin Solid Films 517: 6000-6006.

Gad H.E., and H.H., Gad (2015) "Development of a New Temperature Data Acquisition System for Solar Energy Applications", Renewable Energy Journal, 74: 337-343.

Hiroki G., Mehdi B., Junnosuke O., Atsuki K., and M., Shigenao (2013) "Controlling the Radioactive Properties of Cool BlackColor Coatings Pigmented With Cuo Submicron Particle", Journal of Quantitative Spectroscopy \& Radioactive Transfer.

Ibrahim D., ( 2008) "Advanced PIC Microcontroller Projects in C", Newnes.

James R. G., and W. S., Kenneth (2010) "Measurement of the Solar Absorptance and Thermal Emittance of Lunar Simulants", 40 ${ }^{\text {th }}$ International Conference on Environmental Systems, Barcelona, Spain, July 11-15.

Kalogiroua S., Tripanagnostopoulos Y., and M., Souliotis (2005) "Performance of Solar Systems Employing Collectors with Colored Absorber”, Energy and Buildings 37:824-835. 
Kolokotsa D., Maravelaki K., Papantoniou S., Vangeloglou E., Saliari M., Karlessi T., and M., Santamouris (2012) "Development and Analysis of Mineral Based Coatings for Buildings and Urban Structures", Solar Energy 86:1648-1659.

Lamont, W. J., (1999 ) "The Use of Different Colored Mulches for Yield and Earliness", Proceedings of the New England Vegetable and Berry Growers Conference and Trade Show, Sturbridge, Mass., 299-302.

Nwosu P. N., and I. O., Wilfred (2008) "Effect of an Absorptive Coating on Solar Energy Storage in a Thrombe Wall System", Energy and Buildings $40: 371-374$.

Orela Z. C., Klanjsek G. M., and M.G., Hutchins(2005) "Spectrally Selective Solar Absorbers in Different Non-Black Colours", Solar Energy Materials \& Solar Cells 85:41-50.

Zhu D., and S., Zhao (2010) "Chromaticity and Optical Properties of Colored and Black Solar-Thermal Absorbing Coatings", Solar Energy Materials and Solar Cells 94:1630 - 1635.

الملخص العربي

\section{أمتصاصية أسطح مختلفة مطلية محليا للاشعاع الثمسى بمصر

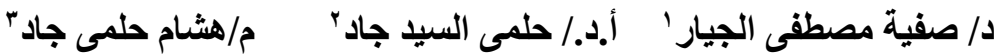

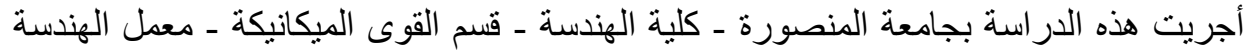

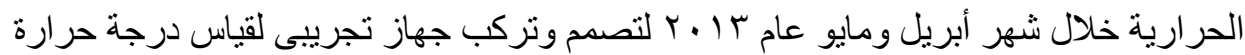

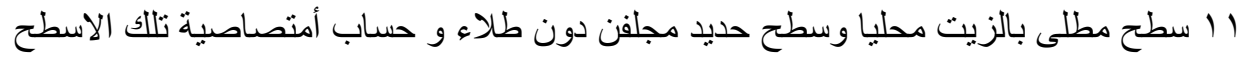

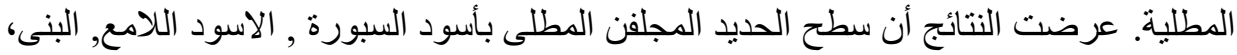

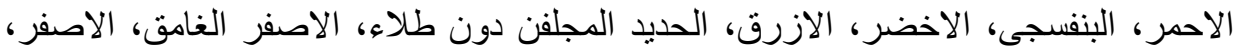

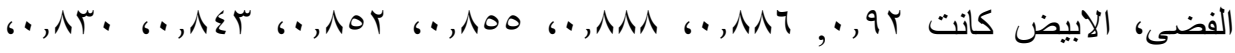

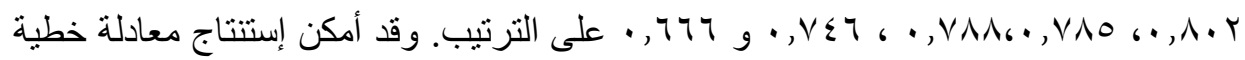
للتنبؤ بأمتصاصية تلاك الاسطح المطلية بألوان الزيت (ه) بناء على درجة حرارتها (T) كما

$$
\begin{aligned}
& \alpha=0.008 \mathrm{~T}+0.053 \quad \mathrm{R}^{2}=0.996 \\
& \text { ويمكن تطبيق هذه المعادلة فى مجال الزر اعة عند إختبار ألوان طلاء المبانى والصوب } \\
& \text { و الثر ائح البلاستيكية المستخدمة لتغطية التربة و السطح الماص (المجمعات الثمسية الثية). } \\
& \text { 1- باحثث أول بمعهد بحوث الهندسة الزراعية ـ مركز البحوث الزراعية ـ الجيزة. }
\end{aligned}
$$

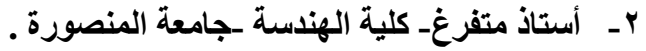

$$
\begin{aligned}
& \text { r- ـ مدرس مساعد كلية الهندسة -جامعة المنصورة . }
\end{aligned}
$$

